\title{
MEMBANGUN KETERAMPILAN BERCOCOK TANAM MELALUI KEGIATAN BERTANAM DENGAN MEDIA HYDROPONIK DI TK AL IRSYAD SURABAYA
}

\author{
Imanida Khusnul Ditajayanti ${ }^{1}$, Aristiana P.R ${ }^{2}$, Aris Setiawan ${ }^{3}$ \\ Universitas Muhammadiyah Surabaya \\ Email: ditajayanti15@gmail.com ${ }^{1}$, aristianapr@yahoo.co.id², \\ wedangmusik@gmail.com
}

\begin{abstract}
ABSTRAK
Penelitian ini dilatarbelakangi oleh kondisi lahan yang sempit di TK Al Irsyad, kritis pertanian di Indonesia, dan tujuan pembelajaran anak usia dini di Indonesia yang mengharuskan anak-anak menguasai berbagai kompetensi untuk kehidupan masa depan mereka. Tujuan dari penelitian ini adalah untuk mengetahui kegiatan pertanian berbasis hidroponik di TK Al Irsyad Surabaya dan pengaruh kegiatan pertanian berbasis hidroponik pada kecerdasan naturalistik anak usia 4-5 tahun. Metode yang digunakan dalam penelitian ini adalah pendekatan kuantitatif. Teknik analisis data dalam penelitian kuantitatif ini menggunakan uji Wilcoxon untuk metode statistik. Sejumlah subjek sampel dalam penelitian ini adalah 20 siswa berusia 4-5 tahun di TK Al Irsyad di Surabaya. Teknik pengumpulan data dalam penelitian ini menggunakan 2 metode yaitu observasi dan dokumentasi. Pengamatan dilakukan dengan menggunakan lembar pretest dan posttest. Hasil pretest menyatakan nilai 5,45 yang berarti sangat jauh dari kemampuan kecerdasan naturalistik anak-anak berusia 4-5 tahun. Perawatannya adalah kegiatan pertanian berbasis hidroponik. Setelah perawatan diberikan kepada siswa, posttest dilakukan dan hasilnya 12,7. Nilai ini meningkat dari hasil pretest. Dapat disimpulkan bahwa kegiatan pertanian berbasis hidroponik memiliki efek pada kecerdasan naturalistik anak-anak pada usia 4-5 di TK Al Irsyad Surabaya.
\end{abstract}

Kata kunci: hidroponik; kegiatan pertanian; kecerdasan naturalistik

\begin{abstract}
This research was motivated by a narrow land condition in Al Irsyad Kindergarten, critical of agriculture in Indonesia, and the goal of early childhood learning in Indonesia which requires children to master various competencies for their future lives. The purpose of this study was to find out hydroponic-based agricultural activities in Al Irsyad Surabaya Kindergarten and the influence of hydroponic-based agricultural activities on naturalistic intelligence of children aged 4-5 years. The method used in this study was a quantitative approach. The data analysis technique in this quantitative study used the Wilcoxon test for the statistical method. A number of subjects sampled in this study were 20 students aged 4-5 years at the Al Irsyad Kindergarten in Surabaya. The data collection techniques
\end{abstract}


in this study used 2 methods i.e. observation and documentation. The observation was made using pretest and posttest sheets. The pretest results stated a value of 5.45 which meant it's so far from naturalistic intelligence ability of children aged 4-5 years. The treatment was a hydroponic-based agricultural activity. After the treatment was given to students, the posttest was conducted and the results were 12.7. This value increased from the results of the pretest. It could be concluded that hydroponic-based agricultural activities had an effect on the children's naturalistic intelligence on aged 4-5 in Al Irsyad Surabaya Kindergarten.

Keywords: hydroponic; agricultural activities; naturalistic intelligence

\section{PENDAHULUAN}

Pendidikan anak usia dini di Indonesia sejak disahkannya UU No.20 tahun 2013 mengalami babak baru. Babak baru itu dapat dikatakan suatu gerakan dari pemerintah yang memposisikan dirinya tampil berada "lebih di depan" dalam menangani pendidikan bagi anak-anak usia dini di Indonesia, yang selama ini juga banyak dijalankan oleh masyarakat (swasta) berupa yayasan pendidikan (Masnipal, 2013).

Fakta otak manusia, saat lahir, otak memiliki seratus miliar neuron atau sel saraf, miliaran neuron ini telah membentuk lebih dari triliun koneksi atau sinapsis, lewat proses yang disebut synaptogenesis, perkembangbiakan koneksi syaraf; proses ini akan berlanjut hingga usia sepuluh tahun (Marrison, 2017). Fakta tentang otak tersebut menjadikan pendidikan anak usia dini diharapkan menjadi masa emas di awal kehidupan anak. Otak yang terstimulasi baik akan memberikan pengaruh positif pada pertumbuhan dan semua aspek perkembangan anak.
Pada masa ini anak akan mengalami berbagai macam proses perkembangan seperti perkembangan fisik, perkembangan bahasa, perkembangan kognitif, perkembangan sosial emosional, dan perkembangan moral. Proses perkembangan anak tersebut membutuhkan pendidikan yang dapat mendorong potensi yang dimiliki anak agar berkembang secara maksimal.

Fakta dalam kajian neurosains, bahwa masa usia emas anak, 0-6 tahun adalah masa dimana sinaps otak manusia berkembang sangat pesat di usia ini, menjadikan masyarakat makin tertarik dengan pendidikan anak usia dini. Masyarakat yang paham akan pentingnya pendidikan anak usia dini berbondong-bondong mendorong buah hatinya ke lembaga pendidikan anak usia dini. Ditambah lagi setiap sekolah TK di Indonesia menawarkan berbagai macam program yang mana dapat menunjang optimalisasi perkembangan anak usia dini. 
Indonesia

menetapkan

pembelajaran ilmiah di dalam

Kurikulum 2013 Pendidikan Anak

Usia Dini dirancang dengan karakteristik sebagai berikut:

1. Mengoptimalkan perkembangan anak yang meliputi: aspek nilai agama dan moral, fisik-motorik, kognitif, bahasa, sosial emosional, dan seni yang tercermin dalam keseimbangan kompetensi sikap, pengetahuan, dan keterampilan.

2. Menggunakan pembelajaran tematik dengan pendekatan saintifik dalam pemberian rangsangan pendidikan.

3. Menggunakan penilaian autentik dalam memantau perkembangan anak.

4. Memberdayakan peran orang tua dalam proses pembelajaran.

Pembelajaran

sainstifik

mengajarkan anak menemukan pengetahuan baru, memecahkan masalah, berpikir kritis dan menciptakan kreativitas sehingga membantu mereka memahami dunia, mengumpulkan dan mengolah informasi sebagai kunci dasar anak belajar berpikir luas. Oleh karena itu kondisi pembelajaran yang diharapkan diarahkan untuk mendorong peserta didik dalam mencari tahu dari berbagai sumber melalui observasi, dan bukan hanya diberi tahu. (Suyadi dan Dahlia, 2014). Maka pendidikan anak usia dini untuk mendapatkan pengalaman belajar yang dapat membantu mereka menguasai banyak kompetensi agar berguna bagi kehidupan sekarang dan kehidupan yang akan datang.

Terkait dengan tujuan pendidikan yang emnyatakan bahwa pendidikan harus diwujudkan dalam suasana yang menyenangkan bagi anak. Terdapat berbagai macam teori belajar yang bisa diterapkan demi menciptakan lingkungan belajar yang menyenangkan dan sesuai minat anak, salah satunya teori kecerdasan jamak. Bainbridge (Muhammad Yaumi, 2013) mendefinisikan kecerdasan sebagai kemampuan mental umum untuk belajar dan menerapkan pengetahuan dalam memanipulasi lingkungan, serta kemampuan untuk berfikir abstrak. Maka, setiap orang memiliki kemampuan mental manakala anak mendapat suatu masalah dalam lingkungannya, anak dapat menyelesaikan dengan cara yang menurut anak benar.

Sedangkan menurut Gardner sebagaimana yang dikutip oleh Thomas R. Hoerr (M. Fadlillah dkk, 2014), mengatakan kecerdasan adalah kemampuan untuk menyelesaikan masalah atau menciptakan sesuatu yang bernilai dalam suatu budaya. Kemampuan menyelesaikan masalah inilah yang akan membantu anak beradaptasi dengan lingkungannya, baik dimasa kini maupun masa depan.

Kecerdasan jamak dimiliki oleh setiap orang sejak ia dilahirkan. Kita semua dilahirkan dengan ketujuh kecerdasan dasar itu, setidaknya dalam suatu derajat tertentu (Julia Jasmine, 2007). Setiap individu terlahir dengan ketujuh dasar 
kecerdasan, tetapi salah satu dari tujuh kecerdasan cenderung lebih tinggi derajatnya ketimbang kecerdasan yang lainnya. Pemberian stimulasi kecerdasan juga berpengaruh pada kesuksesan seseorang. Motivasi bagaimana seseorang bisa lebih unggul di salah satu kecerdasan yang ia miliki dapat diberikan sejak usia dini.

Howard Garner dalam bukunya multiple intelegence menyebutkan terdapat tujuh kecerdasan, ketujuh kecerdasan yang diidentifikasikan oleh Gardner 1983 (Julia Jasmine, 2007) adalah :

1. Kecerdasan linguistik (berkaitan dengan bahasa)

2. Kecerdasan logis-matematis (berkaitan dengan nalar-logika dan matematika)

3. Kecerdasan spasial (berkaitan dengan ruang dan gambar)

4. Kecerdasan musikal (berkaitan dengan musik, irama dan bunyi/suara)

5. Kecerdasan badani-kinestetik (berkaitan dengan badan dan gerak tubuh)

6. Kecerdasan interpersonal, (berkaitan dengan hubungan anatrpribadi, sosial)

7. Kecerdasan intrapersonal, (berkaitan dengan hal-hal yang sangat mempribadi)

Selanjutnya Walter McKenzie

(Muhammad Yaumi, 2013) menggunakan roda domain kecerdasan jamak untuk memvisualisasikan hubungan tidak tetap antara berbagai kecerdasan. Menurutnya kecerdasan dikelompokkan menjadi tiga wilayah atau domain, yanti interaktif, analitik, dan introspektif. Maka terlahirlah 9 kecerdasan jamak dari tiga domain tersebut yaitu ; kecerdasan kinestetik, kecerdasan interpersonal, kecerdasan verbal, kecerdasan musik, kecerdasan logis, kecerdasan naturalistik, kecerdasan eksistensial, kecerdasan intrapersonal, dan kecerdasan visual.

Sehubungan dengan makna kecerdasan yang dikatakan oleh Gardner bahwa kemampuan untuk menyelesaikan masalah atau menciptakan sesuatu yang bernilai dalam suatu budaya. (M. Fadlillah dkk, 2014), masyarakat Indonesia memiliki suatu budaya yang telah mendarah daging yaitu melakukan kegiatan pertanian. Dalam jurnal perubahan iklim dan pertanian indonesia A. Faroby menyatakan bahwa Indonesia merupakan negara Agraris yang besar, dengan penduduknya yang sebagian besar bekerja di sektor pertanian. Kondisi alam inilah yang menjadikan kegiatan pertanian di Indonesia bukanlah hanya menjadi kegiatan bercocok tanam yang menghasilkan hasil pangan. Melainkan sudah menjadi budaya dan urat nadi nya bangsa Indonesia.

Gapoktan Sekar Sari (Sunarso, 2017) mengemukakan bahwa sekarang ini pertanian di Indonesia sedang berada di ambang kritis. Sebagai penunjang kehidupan berjuta-juta masyarakat Indonesia, sektor pertanian memerlukan pertumbuhan ekonomi yang kokoh dan pesat. Fakta ini menjadi masalah 
yang harus segera dicari solusi untuk menyelamatkan kehidupan bangsa Indonesia di masa yang akan datang.

Kegiatan pertanian termasuk jenis kegiatan yang menstimulasi perkembangan kecerdasan naturalistik. Carvin (dalam Muhammad Yaumi, 2013) menyatakan bahwa kecerdasan naturalistik adalah kemampuan seseorang untuk mengidentifikasi dan mengklarifikasi pola-pola alam (nature). Seseorang yang memliki keahlian mengidentifikasi berbagai jenis flora dan fauna maka ia memiliki kecerdasan naturalistik dalam tingkat tinggi. Kemampuan ini bisa di stimulasi tingkat kemampuannya sejak anak berusia dini.

Yasbiati dkk dalam penelitiannya yang berjudul "Upaya Meningkatkan Kecerdasan Naturalis Melalui Kegiatan Bercocok Tanam Di Bimbim Al Abror Kecamatan Mangkubumi Kota Tasikmalaya" menyimpulkan bahwa kegiatan bercocok tanam mampu menarik perhatian anak untuk lebih menyayangi tanaman, mengetahui apa saja bagian tanaman, dan merawat tanaman. Senada dengan hasil penelitian yang dilakukan Yasbianti maka dilakukanlah penelitian dengan kegiatan yang sama yaitu becocok tanam tetapi berbeda metode. Kegiatan pertanian yang dilakukan kali ini berbasis hidroponik.

Lokasi sekolah TK Al Irsyad berada di tengah-tengah perkampungan warga, bangunannya mirip rumah yang dimodifikasi menjadi sekolahan. Lahan yang tidak terlalu besar untuk melakukan penghijauan tidak membatasi pihak sekolah untuk melakukan penanaman. Sekolah melakukan penanaman bersistem hidroponik yang di gantung di depan-depan kelas. Penghijauan ini memiliki tujuan untuk mengenalkan anak didik pada alam, meskipun tidak banyak kuantitas tanaman yang terdapat di sekolahan tapi cukup untuk memberi pengetahuan pada anak tentang ciptaan Allah dan cara mensyukuri nikmatnya.

Anak didik di TK Al Irsyad mendapatkan pembiasaan merawat dan menjaga kelestarian tanaman hidroponik. Kegiatan pembiasaan setiap pagi untuk menyiram dan membersihkan sampah yang ada disekitar tanaman menjadi kegiatan pembelajaran untuk mengasah kecerdasan naturalistiknya. Anak didik dapat peduli pada lingkungan sekitar sebagai wujud rasa syukur terhadap Allah SWT.

Kepedulian pada lingkungan dan kemampuan bercocok tanam akan membangun kepedulian anak pada lingkungan hidup. Kepedulian pada lingkungan hidup pada anak diperlukan karena bangsa ini sedang menghadapi krisis lingkungan. Banyak lingkungan hidup tidak terawat bahkan rusak karena ulah oknum masyarakat yang tidak bertanggungjawab. Maka sebuah kebutuhan untuk melahirkan generasi-generasi penerus yang memiliki kepedulian besar pada 
lingkungan, tentu dengan harapan bahwa generasi inilah nantinya yang akan memperbaiki lingkungan hidup yang saat ini tengah terancam kerusakan.

Kemampuan dalam kecerdasan naturalistik juga dapat terasah dalam kegiatan pertanian ini. Hal ini mendorong penulis mengkaji kegiatan pertanian pada anak untuk perkembanagn kecerdasan naturalistik yang ada di TK Al Irsyad. Berdasarkan uraian diatas penulis terdorong untuk melakukan penelitian tentang "MEMBANGUN KETERAMPILAN BERCOCOK TANAM MELALUI KEGIATAN BERTANAM DENGAN MEDIA HYDROPONIK DI TK AL IRSYAD SURABAYA " (studi kasus TK Al Irsyad Surabaya).

Adapun tujuan penelitian ini yaitu: (1) Mengetahui kegiatan pertanian berbasis hidroponik yang ada di TK Al Irsyad Surabaya untuk anak usia 45 tahun. (2) Mengetahui pengaruh kegiatan pertanian berbasis hidroponik terhadap keterampilan bercocok tanam TK Al Irsyad Surabaya untuk anak usia 4-5 tahun

\section{METODE PENELITIAN}

Penelitian ini dilakukan menggunakan metode penelitian kuantitatif dengan desain penelitian Pre-Eksperimental One-Group Pretest-Posttest Design. Instrument yang digunakan berupa lembar observasi keterlaksanaan kegiatan pembelajaran, Pretest, dan Posttest. Instrumen yang dilakukan memiliki tujuan untuk mengukur perkembangan kecerdasan naturalistic anak usia 4-5 tahun. Adapun teknik untuk memproleh data yaitu menggunakan rubrik penelitian

\section{HASIL PENELITIAN}

Penelitian ini menggunakan data hasil pengamatan untuk mengetahui pengaruh kegiatan pertanian berbasis hidroponik terhadap kemampuan bercocok tanam anak usia 4-5 tahun. Observasi ini dilakukan ketika pre-test dan post-test. Pada tahapan pre-test, peneliti belum memberikan sebuah perlakuan (Treatment) kepada kelompok A. Pada tahapan post-test, peneliti sudah memberikan sebuah perlakuan (Treatment) kepada kelompok A.
Data yang diperoleh dari hasil pre-test dan post-test akan dihitung dengan menggunakan Uji Wilcoxon Match Pairs Test yang digunakan untuk menguji hipotesis nihil $\left(\mathrm{H}_{\mathrm{o}}\right)$. Menguji hipotesis nihil $\left(\mathrm{H}_{\mathrm{o}}\right)$ yang menyatakan bahwa tidak terdapat pengaruh dengan kegiatan pertanian berbasis hidroponik terhadap kemampuan bercocok tanam anak usia 4-5 tahun. Kriteria yang digunakan dalam menguji hipotesis nihil penelitian ini yaitu memakai taraf kesalahan 5\% atau 0,005. 
Adapun hasil perhitungan data dengan menggunakan Uji
Wilcoxon Match Pairs Test yaitu:

\section{Wilcoxon Match Pairs Test}

\begin{tabular}{|c|c|c|c|c|c|c|c|}
\hline \multirow{2}{*}{ No. } & \multirow{2}{*}{ Nama } & \multirow{2}{*}{$\mathbf{X}_{\mathrm{A1}}$} & \multirow{2}{*}{$\mathbf{X}_{\mathbf{B} 1}$} & Beda & \multicolumn{3}{|c|}{ Tanda Jenjang } \\
\hline & & & & $\mathbf{X}_{\mathrm{B} 1}-\mathbf{X}_{\mathrm{A} 1}$ & Jenjang & + & - \\
\hline 1 & Muhamad & 5 & 14 & 9 & 10.8 & 10.8 & 0 \\
\hline 2 & Abdullah A. & 4 & 13 & 9 & 10.8 & 10.8 & 0 \\
\hline 3 & Abdullah K. & 6 & 12 & 6 & 11 & 11 & 0 \\
\hline 4 & Bintang & 6 & 14 & 8 & 9.4 & 9.4 & 0 \\
\hline 5 & Rahman & 4 & 15 & 11 & 5 & 5 & 0 \\
\hline 6 & Fadil & 5 & 13 & 8 & 9.4 & 9.4 & 0 \\
\hline 7 & Tsaqief & 6 & 13 & 7 & 11 & 11 & 0 \\
\hline 8 & Naufal & 4 & 12 & 8 & 9.4 & 9.4 & 0 \\
\hline 9 & Azzam & 6 & 14 & 8 & 9.4 & 9.4 & 0 \\
\hline 10 & Raihan & 6 & 7 & 1 & 15 & 15 & 0 \\
\hline 11 & Avika & 6 & 11 & 5 & 11 & 11 & 0 \\
\hline 12 & Nindy & 7 & 15 & 8 & 9.4 & 9.4 & 0 \\
\hline 13 & Rumaisa & 5 & 13 & 8 & 9.4 & 9.4 & 0 \\
\hline 14 & Raisa & 5 & 13 & 8 & 9.4 & 9.4 & 0 \\
\hline 15 & Afaf & 6 & 13 & 7 & 11 & 11 & 0 \\
\hline 16 & Farah & 6 & 15 & 9 & 10.8 & 10.8 & 0 \\
\hline 17 & Asiyah & 6 & 15 & 9 & 10.8 & 10.8 & 0 \\
\hline 18 & Shereen & 4 & 13 & 9 & 10.8 & 10.8 & 0 \\
\hline 19 & Zara & 6 & 12 & 6 & 11 & 11 & 0 \\
\hline 20 & Aisyah & 6 & 7 & 1 & 15 & 15 & 0 \\
\hline \multicolumn{6}{|c|}{ Jumlah } & 209.8 & 0 \\
\hline
\end{tabular}

Berdasarkan hasil analisis data di atas disimpulkan bahwa hipotesis nihil (Ho) yang menyatakan "tidak ada pengaruh kegiatan pertanian berbasis hidroponik terhadap kemampuan bercocok tanam anak usia 4-5 tahun adalah tidak benar". Jadi, hasil analisis data yang mengacu pada hasil pre-test dan post-test mampu menguji kebenaran hipotesis nihil (Ho) yang ditolak 
sehingga dapat menghasilkan kebenaran bahwa terdapat pengaruh pengaruh kegiatan pertanian berbasis hidroponik terhadapkemampuan bercocok tanam anak usia 4-5 tahun

\section{PEMBAHASAN}

Hasil analisis data diperoleh dari data hasil pre-test dan data hasil post-test yang kemudian dicari nilai selisih dari kedua tahapan penelitian tersebut, sehingga nilai yang dihasilkan yaitu sebuah nilainilai jenjang yang akan menentukan $\mathrm{H}$ hitung untuk digunakan dalam menguji hipotesis nihil (Ho). Hasil analisis data yang diperoleh yaitu dengan menggunakan Uji Wilcoxon Match Pairs Test yang menghasilkan nilai $\mathrm{T}_{+}$sebanyak 209.8 dan $\mathrm{T}$ - hanya bernilai 0 . Hasil tersebut memiliki arti bahwasannya nilai selisih yang berasalkan dari hasil pre-test dan post-test mengalami perkembangan sedangkan untuk data $\mathrm{T}$ - merupakan nilai selisih antara kedua proses pengambilan data mengalami penurunan.

Menentukan nilai $\mathrm{T}$

hitung yaitu berdasarkan kedua nilai $\mathrm{T}$ dengan memilih nilai $\mathrm{T}$ yang terkecil dan pada penelitian ini nilai $\mathrm{T}$ - bernilai 0 . Kemudian nilai $\mathrm{T}$ - dibandingkan $\mathrm{T}$ tabel yang diambil dari tabel kritis untuk Test Wilcoxon (Uji T) yaitu dengan $\mathrm{N}=20$ maka bernilai 52 dengan taraf kesalahan $5 \%$ atau 0,05 . Hasil dari pengujian tersebut menyatakan bahwa "hipotesis nihil ditolak" dan juga dapat disimpulkan bahwa "terdapat pengaruh kegiatan pertanian berbasis hidroponik terhadap kemampuan bercocok tanam pada anak usia 4-5 tahun”.

Hasil pengamatan lapangan sebelum dan sesudah perlakuan menunjukkan beberapa faktor yang menyebabkan naiknya nilai kecerdasanan anak usia 4-5 tahun di TK Al Irsyad Surabaya, kenaikan nilai kecerdasan naturalistik anak sangat berpengaruh pada hasil kegiatan pertanian berbasis hidroponik terhadap kecerdasan naturalistik anak, maka ditemukan beberapa penyebab anak memiliki kenaikan nilai dalam jumlah besar dan anak yang memiliki kenaikan nilai dalam jumlah kecil.

Adapun beberapa faktor yaitu persentase kehadiran siswa saat kegiatan pertanian menjadi penyebab yang berpengaruh pada keaktifan anak dalam mengikuti kegiatan pertanian berbasis hidroponik. Kematangan motorik kasar dan halus anak mempengaruhi anak saat melakukan proses kegiatan pertanian, anak yang memiliki kematangan dalam motoriknya akan lebih cepat saat melakukan kegiatan pertanian berbasis hidroponik (bercocok tanam). 


\section{KESIMPULAN}

Berdasarkan data hasil penelitian dapat disimpulkan bahwa membangun keterampilan bercocok tanam melalui kegiatan bertanam media hydroponik mampu mendorong anak memiliki kecintaan pada lingkungan. Selain itu keterampilan bercocok tanam pada anak usia dini mampu menstimulasi aspek kognitif anak, terutama tentang jenisjenis tanaman tentang bagianbagian tanaman. Mengenal benda-benda apa yang dibutuhkan tanaman untuk hidup misalya air, tanah, cahaya matahari, dsb. Pengetahuan tentang flora dan bagaimana menanam serta merawatnya akan mampu membentuk anak menjadi pribadi yang penuh kasih sayang pada makhluk hidup lainnya.

\section{DAFTAR PUSTAKA}

Fadlillah, M. 2014. Edutainment Pendidikan Anak Usia Dini. Jakarta : Prenada Group Kencana

Gardner, H. 2003. Kecerdasan Majemuk (Multiple Intelegences) teori dalam praktek Howard Gardner. Batam : Interaksara.

Hartiwi, Tri. 2014. JPeningkatan Kecerdasan Naturalis Melalui Metode Eksperimen Pada Kelompok B di TK Al Islam kabupaten Sragen Tahun Ajaran 2013/2014.

(http://eprints.ums.ac.id/28953/ , diakses 5 Desember 2018)

Iqbal, Muhammad. 2016. Simpel Hidroponik - dimanapun.... kapan pun... siapa pun... bisa bertanam hidroponik. Yogyakarta: Lily Publisher. Jasmine, Julia. 2007. Mengajar Dengan Metode Kecerdasan Majemuk (Implementasi multiple intelegences). Bandung : Penerbit Nuansa.

Juniarti, Yenti. Jurnal pendidikan anak usia dini Vol.9 No.2 Peningkatan Kecerdasan Naturalis Melalui Metode Kunjngan Lapangan (Field Trip) Penelitian Tindakan di Kelompok BPAUD Terpadu Bintuhan Bengkulu, Tahun 2015 (http://journal.unj.ac.id/u nj/index.php/jpud/article/ view/3505, diakses 28 Desember 2018)

Marrison, George. 2017. DasarDasar Pendidikan Anak Usia Dini (PAUD). Jakarta : PT. indeks.

Mufidati, N. 2018. Pengaruh Media Pick Me terhadap perkembangan Sosial Anak Usia 5-6 Tahun di TK Aisiyah 33 Surabaya. Surabaya : Universitas Muhammadiyah Surabaya. 
Mundir, H. 2013. Statistik Pendidikan. Yogjakarta : Pustaka Pelajar bekerjasama dengan STAIN Jember Press

Riyanto, Y. 2001. Metodelogi Penelitian Pendidikan. Surabaya : Anggota IKAPI.

Sarwono, Jonathan. 2006. Metode Penelitian Kuantitatif \& Kualitatif. Yogyakarta : Graha Ilmu. Sarjono, Haryadi \& Julianita, Winda. 2013. SPSS VS LISREL : Sebuah Pengantar, Aplikasi Untuk Riset. Jakarta : Penerbit Salemba.

Seefeldt, Carol \& Wasik, Barbara. 2008.

Pendidikan anak usia dini (menyiapkan anak usia tiga, empat, dan lima masuk sekolah). Jakarta : PT. indeks.

Soefandi, Indra \& Pramudya, Ahmad. 2009. Strategi Mengembangkan Potensi Kecerdasan Anak. Jakarta: Bee Media Indonesia.

Sugiyono. 2015. Statistik Nonparametris Untuk Penelitian, Bandung : Alfabeta.

Syamsu, Ida R. Jurnal Universitas Tulungagung
BONOROWO Vol.

1.No.2. Pemanfaatan Lahan Dengan

Menggunakan Sistem Hidroponik (http://junalunita.org/index.php/bono rowo/article/,diakses 15 Desember 2018)

Thoifah, I'anatut. 2015. Statistika Pendidikan Dan Metode Penelitian Kuantitatif. Malang : Madani.

Yaumi, Muhammad \& Ibrahim, Nurdin. 2013.

Pembelajaran Berbasis

Kecerdasan Jamak (Multiple Intellegences). Jakarta: Kencana Prenadamedia Group.

Yasbianti \& Rosarina Giyartini, Annisa Lutfiana. Jurnal PAUD Agapedia Vol.1 No.2 Upaya Meningkatkan

Kecerdasan Naturalis Melalui Kegiatan Bercocok Tanam di BAMBIM AL-ABROR Kecamatan Mangkubumi Kota Tasikmalaya (http://ejournal.upi.edu/i ndex.php/agapedia/articl e/view/9360, diakses 01 Desember 2018) 